\title{
Overtime and quality of working life in academics and non-academics: the role of perceived work-life balance
}

Article

Accepted Version

Fontinha, R., Easton, S. and Van Laar, D. (2019) Overtime and quality of working life in academics and non-academics: the role of perceived work-life balance. International Journal of Stress Management, 26 (2). pp. 173-183. ISSN 1072-5245 doi: https://doi.org/10.1037/str0000067 Available at https://centaur.reading.ac.uk/70687/

It is advisable to refer to the publisher's version if you intend to cite from the work. See Guidance on citing.

To link to this article DOI: http://dx.doi.org/10.1037/str0000067

Publisher: American Psychological Association

All outputs in CentAUR are protected by Intellectual Property Rights law, including copyright law. Copyright and IPR is retained by the creators or other copyright holders. Terms and conditions for use of this material are defined in the End User Agreement.

www.reading.ac.uk/centaur 
Central Archive at the University of Reading

Reading's research outputs online 
Running Head: OVERTIME AND QUALITY OF WORKING LIFE IN ACADEMICS

Overtime and Quality of Working Life in Academics and non-Academics:

The Role of Perceived Work-life Balance 
Running Head: OVERTIME AND QUALITY OF WORKING LIFE IN ACADEMICS

\begin{abstract}
While academic jobs generally provide a good degree of flexibility, academics also tend to work extra hours which can then lead to a poorer work-life balance. In this study, we compare academic vs. non-academic staff and anticipate that academics will generally report a poorer Quality of Working Life, a broad conceptualization of the overall work experience of employees. Secondly, we investigate whether the negative relationships between being an academic and Quality of Working Life variables are made worse by working extra hours, and moderated by the perception of having a balanced work-life interface. Our sample consisted of 1474 academic and 1953 non-academic staff working for nine Higher Education Institutions (HEIs) in the United Kingdom (UK). Data were analyzed via structural equation modelling.
\end{abstract}

Results showed that academics tend to report a poorer Quality of Working Life than non-academics within HEIs, and this is exacerbated by their higher reported number of extra hours worked per week. The work-life balance of employees was found to moderate the negative relationships between academics (vs. non-academics) in variables such as perceived working conditions and employee commitment. We additionally found curvilinear relationships where employees who worked up to 10 extra hours were more satisfied with their job and career and had more control at work than those who either did not work extra hours or worked for a higher number of extra hours. These results extend previous research and provide new insights on work-life balance among academics and non-academics, which in turn may be relevant for the wellbeing practices of HEIs and wider HE policy making. Keywords: Quality of Working Life; Academics; Working Over-Time; Work-Life Balance 
Running Head: OVERTIME AND QUALITY OF WORKING LIFE IN ACADEMICS

Academic jobs used to be considered privileged roles associated with relatively low stress levels in a sense that they provided flexibility, autonomy and job security after tenure was achieved. However, this general assumption has been changing over the past 20 years, with increasing productivity demands, not only in terms of research, but also in terms of teaching and administrative activities (Kinman, 2014). This relates to institutional reforms that Higher Education Institutions in many OECD countries have been experiencing, which have led them to a more market-oriented perspective (Whitley \& Gläser, 2014). The increased productivity demands have been associated with high reported stress levels among academics (e.g., Catano et al., 2010; Coetzee \& Rothmann, 2005; Kinman, Jones, \& Kinman, 2006; Tytherleigh, Webb, Cooper, \& Ricketts, 2005; Winefield, Boyd, Saebel, \& Pignata, 2008), and there is evidence that academics feel their stress levels are increasing (Kinman \& Wray, 2016). High levels of stress, in particular distress (e.g. Le Fevre, Matheny $\&$ Kolt, 2003) are an important element within an individual's overall quality of working life. Quality of working life can be defined as the broadest context in which an employee evaluates their work experience (Van Laar, Edwards \& Easton, 2007) and comprises multiple factors. These different factors will be the specific outcome variables in this study. We will focus on the quality of working life of academics vs. non-academics in nine British Universities as the overarching outcome in our research model.

First, we anticipate that when compared to non-academics, academics would have more demanding jobs because of the diversity of tasks and the number and quality of expected outputs of their work (e.g. Kinman, 2014). For this reason, academics are likely to perceive a poorer quality of working life and in particular to report higher levels of stress at work (SAW), lower levels of control at work (CAW), have a less favorable perception of their working conditions (WCS), have a poorer job and career satisfaction (JCS), have lower 
Running Head: OVERTIME AND QUALITY OF WORKING LIFE IN ACADEMICS

levels of commitment to the organization (ECO) and have lower levels of general well-being (GWB).

Secondly, we assess the way in which the reported weekly number of extra hours worked and individual perceptions about how their organization promotes their work-life balance can act as moderators in the relationship between role (academic vs. non-academic) and SAW, CAW, WCS, JCS, ECO and GWB. In particular, we assume that a high number of extra hours worked will enhance the negative relationship between being an academic (vs. non-academic) and quality of working life outcomes, whereas perceived promotion of worklife balance by the Higher Education Institution (HEI) would buffer these negative relationships.

This study has three important contributions for existing research on academics and non-academics in HEI:

1- Previous research has compared academics with non-academics in relation to a number of areas: stress, commitment to and from the organization, physical health, psychological health (Tytherleigh at al., 2005), psychological strain and job satisfaction (Winefield at al., 2003). We now aim to extend this body of research by considering a different overarching measure -that of quality of working life.

2 - There is an important body of research on working extra hours (e.g. Coetzee \& Rothmann, 2005; Court, 1996; Kinman et al., 2006; Kinman \& Wray, 2013) and on work-life balance (e.g. Currie \& Eveline, 2011; Doherty \& Manfredi, 2006; Kinman \& Jones, 2008; Noor, 2011; Pillay \& Abhayawansa, 2014; Pillay, Kluvers, Abhayawansa \& Vranic, 2013) among academics. However, we are among the first to consider the way these two variables might interact with role (academic vs. non-academic) in its relationship with the different factors within quality of working life. This is of particular relevance as it allows us to explore different patterns of role and working extra hours, and role and work-life balance, 
Running Head: OVERTIME AND QUALITY OF WORKING LIFE IN ACADEMICS

providing a more thorough analysis of the antecedents of various factors affecting quality of working life. This represents the second major contribution of our paper.

3 - The third and last contribution of this study relates to the exploration of the role of working extra hours on the different factors within quality of working life. In particular, we test curvilinear relationships between number of extra hours worked per week and JCS, WCS, CAW, absence of SAW, ECO and GWB in order to explain unexpected direct relationships found in our structural model.

\section{Academics vs Non-Academics' Quality of Working Life}

The broadest context in which a person evaluates or considers their personal situation has been termed their Quality of Life (Felce \& Perry, 1995). Thus, 'Quality of Working Life' of an individual can be conceived of as the broadest context in which an employee evaluates their work experience (Elizur \& Shye, 1990). Whilst early conceptualizations of quality of working life sought to identify global definitions and create all-encompassing models, Taylor, Cooper, and Mumford (1979) were among the first to suggest that quality of working life might vary between organizations and employee groups. It was perhaps because researchers sought to understand quality of working life in various professions, countries and cultures that an ever-growing list of possible sub-factors were identified (Van Laar et al., 2007).

The development of models of quality of working life has led to focused research on factors specific to each theory, but other researchers have continued to explore the broader concepts of quality of working life in the applied setting, exploring more complex relationships between selected factors, mediators and outcomes (e.g. work by Denvir, Hillage, Cox, Sinclair, \& Pearmain, 2008). A measure of Quality of Working life used in more than 30 countries, the 'Work-Related Quality of Life scale' (WRQoL), was used in the present study (Easton \& Van Laar, 2012; Fontinha, Van Laar \& Easton, 2016). This scale 
Running Head: OVERTIME AND QUALITY OF WORKING LIFE IN ACADEMICS

contains six factors: individual's perceptions of whether their organization provides them with a balanced home-work interface (HWI) - this will be an independent variable in our model named work-life balance; perceptions about the physical working conditions available (WCS); job and career satisfaction (JCS); perceptions regarding the level of control over decision making at work (CAW); levels of stress, or its absence, at work (SAW); and general well-being (GWB). A seventh factor, which assesses level of employee commitment to the organization (ECO) has been used in ongoing research and development of the WRQoL scale, and is also used here (Fontinha et al., 2016). We focus on these dimensions, the dependent variables in our model, in order to characterize the quality of working life of academics and non-academics working in nine HEIs in the United Kingdom.

Numerous studies have reported that academics consider their work stressful (e.g., Catano et al., 2010; Coetzee \& Rothmann, 2005; Kinman et al., 2006; Tytherleigh et al., 2005; Winefield et al., 2008), and there is evidence that they feel stress levels are increasing (Kinman \& Wray, 2016) in association with changes in the University sector (Whitley \& Gläser, 2014). This increase in reported stress appears to be associated with reported distress at levels which exceed many other occupational groups (Edwards et al., 2009; Winefield et al., 2008). These high stress levels among academics may be a response to different workrelated aspects, as suggested by the Job Demands-Resources (JD-R) model (Demerouti, Bakker, Nachreiner, \& Schaufeli, 2001). The JD-R model posits that work overload, among other factors, can adversely affect physical and psychological wellbeing, whereas sense of control at work and social support enhance productivity [by way of improved motivation, according to Schaufeli and Taris (2014)]. We follow the same rationale in this study, conceptualizing stress as a response to specific work-related stimuli (demands). However, we go further by considering multiple factors that compose one's quality of working life as outcomes (stress being one factor within quality of working life). 
A substantial increase in the number of non-academic staff employed by universities across the world has been recently reported (Larkins, 2014). There has been little attention paid to the working experience of non-academic staff (Johnsrud, 2002), but there do appear to be differences between the two staff groups as regards experience of working in the university sector, as indicated for example in an Australian study wherein $74 \%$ of nonacademic staff reported overall job satisfaction, but only $61 \%$ of academic staff reported overall job satisfaction (Winefield et al., 2003). UK academic staff surveys have also increasingly reported increases in teaching loads and fears concerning job security alongside reductions in job satisfaction for academics (Metcalf, Rolfe, Stevens \& Weale, 2005; Tytherleigh et al., 2005). UK academics have high levels of perceived control at work, but these have been progressively decreasing (Kinman \& Wray, 2016).

These findings suggest that academics generally have a much lower perceived quality of working life compared to non-academics. Accordingly, we hypothesize:

H1 - Academics perceive a poorer quality of working life in terms of WCS, JCS, CAW, SAW, ECO and GWB, when compared to non-academics.

\section{Working extra hours and Work-Life Balance in Higher Education}

Kinman (2014) suggested that the work of academics has, over the last 20 years, become more demanding as student numbers have increased and academics are expected to excel at teaching as well as research. Furthermore, data from the Annual Survey of Hours and Earnings provides evidence that teaching and education professionals in schools, colleges and universities do extra unpaid work each week, more than any other group of professionals (Statistical Bulletin, 2013). Kinman \& Wray (2013) have reported that over a third of UK academics surveyed stated that they regularly work more than 10 hours in addition to their contract per week, which has been linked to adverse consequences in relation to physical and 
Running Head: OVERTIME AND QUALITY OF WORKING LIFE IN ACADEMICS

psychological wellbeing (Doyle \& Hind, 1998; Gillespie, Walsh, Winefield, \& Stough, 2001; Kinman \& Jones, 2004).

Fein and Skinner (2015) concluded from a survey of 1042 full-time workers in Australia that work-life conflict as a result of working long hours tended to adversely affect health outcomes. A study of more than 2500 academic staff using work diaries revealed an average working week of almost 55 hours during term time (Court, 1996) and a subsequent report by Kinman (1998) stated that almost three-quarters of academics indicated that working during evenings and weekends was commonplace. Long working hours have been linked to psychological and physical ill-health, and that association appears to be greater where the average working week regularly exceeds 48 hours and the individual perceives little job control (Sparks, Cooper, Fried, \& Shirom, 1997). In the HE context, Kinman (1998) reported that academics who said they worked over 50 hours per week, or who took work home on a regular basis, tended to score more poorly on assessments of psychological wellbeing. More recent data shows that more than three-quarters of academics employed on a full-time contract (typically 37.5 hours) worked over 40 hours a week, and more than one third in excess of 50 hours a week (Kinman \& Wray, 2016). These results lead us to anticipate that while academics would normally report a poorer quality of working life than their non-academic counterparts, this relationship may be exacerbated by a high number of extra hours worked per week. Thus, we hypothesize:

H2 - A higher number of extra working hours increases the negative relationship between being an academic (vs. a non-academic) and elements of quality of working life (WCS, JCS, CAW, SAW, ECO and GWB).

Work-life balance can be defined as the individual perception that work and nonwork activities are compatible and promote growth in accordance with an individual's current 
Running Head: OVERTIME AND QUALITY OF WORKING LIFE IN ACADEMICS

life priorities (Kalliath \& Brough, 2008). Various studies have reported that balancing of work and home can be difficult for academics (Netemeyer, Boles \& McMurrian, 1996; Winefield, Boyd \& Winefield, 2014), particularly due to time-based conflict (time spent working at the expense of time devoted to family/leisure activities) and strain-based conflict (job related strain leads to irritability and social withdrawal). Menzies and Newson (2007) highlight the potentially adverse influence of the increase in working from home, and others, including Boswell \& Olson-Buchanan (2007) and Araujo (2008), have suggested that it is the blurring of boundaries between work and home rather than working from home per se that can be the cause of difficulty, although there is evidence that a sense of control over working patterns among academics can be helpful (Kinman \& Jones, 2004).

Siegrist (1996) has proposed in the effort-reward imbalance (ERI) model that the experience of imbalance will be more frequent and more damaging in employees who are excessively committed to work, where overcommitment is defined as attitudes, behaviors and emotions that reflect a strong desire for approval and esteem which can lead to working excessively (Siegrist, 2001). The ERI model was empirically tested by Kinman \& Jones (2008) who showed that effort-reward imbalance is particularly damaging for the work-life balance of university workers, who cope with work demands by overcommitting and working additional hours over and above their contract. High levels of overcommitment in academics have been found in a culture where working long hours and a relatively poor work-life balance can be more widely accepted (Hogan, Hogan, Hodgins, Kinman, \& Bunting, 2014). Whilst enjoyment of and commitment to work can have health benefits and enhance career success (Kelloway et al., 2010), overcommitment has been reported to increase risk of stress (Avanzi, van Dick, Fraccaroli, \& Sarchielli, 2012; Kinman \& Wray, 2016). Furthermore, Greenhaus and Beutell's (1985) suggested that role pressures from work and family settings can be mutually incompatible to a greater or lesser degree, as workers perceive they have too 
little time for work and family commitments, and as they may experience stress, exhaustion and fatigue which adversely affect their psychological and physical wellbeing (Greenhaus \& Beutell 1985).

Hobfoll (1989) suggested that employees experience stress when there is actual or threatened loss of valued resources. Thus, a balanced work-family interface (also referred to as work-life balance or home-work interface) has been identified as such a positive resource for individuals and therefore associated with an amelioration or absence of stress (Chiang, Birtch \& Kwan, 2010). Most studies on the outcomes of a balanced work-life interface aim to understand its implications on stress. In this study we aim to extend this body of research and consider the way the organizational context facilitates work-life balance as a relevant resource that academics can utilize to buffer the negative effects of excessive demands of their roles on their quality of working lives (including, but not limited to stress). In particular, we hypothesize that:

$\mathrm{H} 3$ - The negative relationship between being an academic (vs. non-academic) and elements of quality of working life (WCS, JCS, CAW, SAW, ECO and GWB) is moderated by one's perception of an organizational context facilitating work-life balance.

Figure 1 presents a model with all hypothetical relationships tested, acknowledging the role of four control variables: age, gender, tenure and contract type (permanent vs. temporary).

Figure 1. Relationships between role and quality of working life factors and interaction effects with additional working hours and work-life balance

(insert figure 1 about here)

Notes for Figure 1: Observed variables represented in a rectangle; Latent variables represented in an ellipse; * represents interaction effects between two variables; for ease of 
presentation the regression paths between all observed variables and all latent variables are represented by the large central arrow.

\section{Method}

\section{Data Collection and Participants}

We contacted a large number of Higher Education Institutions (HEI) in the UK asking them to participate in our study. The data from nine British HEIs were employed in this study, three from the top third, three from the middle third and three from the bottom third of UK University league tables (The Complete University Guide, 2017; University League Tables by The Guardian, 2017). The average position in the ranking was calculated considering the two sources of league tables at the time of data collection (2007-2009). All nine Human Resources departments emailed all their employees our request to participate in this study and the link to our web-based questionnaire. This resulted in a total of 3,771 responses with an average response rate of $32.54 \%$. We deleted all cases with missing data on the variables that we were analyzing, which resulted in a total of 3427 usable cases. The total number of academics in our sample was $1474(43 \%)$ and the total number of non-academics was 1953 (57\%). According to data from the Higher Education Statistics Agency (HESA, 2016), this proportion of academics and non-academics is consistent with the national average proportion for the year of data collection, 2007: $46.97 \%$ for academics and $53.03 \%$ for non-academics. Non-academics predominantly performed computer-based support tasks. A detailed description of our sample based on gender, age, tenure (representing the number of years working for their current Higher Education Institution), number of extra-hours worked per week, contractual time (full-time, part-time, part-time hourly paid, or no fixedhours) and contract type (temporary vs. permanent) is presented on Table 1. 
Running Head: OVERTIME AND QUALITY OF WORKING LIFE IN ACADEMICS

We conducted one-way ANOVAs with post-hoc Bonferroni tests in order to investigate whether there were significant differences between the core characteristics of academics and non-academics in the nine different HEIs studied. We compared all HEIs based on the main variables in our study and the most relevant result was that no significant differences were found between the nine HEIs regarding the number of extra hours that academics work per week $(\mathrm{F}=1.94 ; \mathrm{p}>.05)$. However, non-academics working for higher ranked universities worked for more hours than their counterparts that worked for lower ranked universities $(\mathrm{F}=14.77 ; \mathrm{p}<.001)$.

\section{Measures}

All outcome variables in our hypothesized model, as well as work-life balance were measured with Easton and Van Laar's (2012) WRQoL1 (Work-related Quality of Life) scale. The WRQoL1 scale has been used in a wide range of settings and organizations across the world and has been translated into various languages (e.g. Blanch, Sahagún, Cantera, \& Cervantes, 2010; Dehghan, Tahmineh \& Asadi, 2011; Easton \& Van Laar, 2013; Vagharseyyedin, Vanaki, \& Mohammadi, 2011). Three items representing employees’ commitment to the organization were added to the scale and validated in a recent study (Fontinha et al., 2016). We used this updated 26-item version of the scale in this study. This scale comprises seven factors: working conditions (WCS), job and career satisfaction (JCS), control at work (CAW), employee commitment (ECO), (absence of) stress at work (SAW), general well-being (GWB), and home-work interface (HWI). For the purpose of consistency with previous literature and a clearer understanding of the meaning of the HWI factor, we have decided to address it as work-life balance in this study. All items are scored on a 5-point Likert scale from $1=$ 'Strongly disagree' to $5=$ 'Strongly agree'. A detailed description of each factor is presented below. 
Work-Life Balance. This construct was measured using the three HWI items of the WRQoL1 scale (Easton \& Van Laar, 2012; Fontinha et al., 2016) and refers to the perceived context provided by the organization to have a balance between work and personal life. This factor has a sub-scale reliability of $\alpha=.85$ in these data and picks up on the importance of balancing home and work demands (Dorsey, Jarjoura \& Rutecki, 2003). One example item is: "My current working hours/patterns suit my personal circumstances".

Working Conditions (WCS). This construct assesses the extent to which someone is satisfied with their physical working environment. Reliability for this sub-scale was $\alpha=0.79$ and an example item is: "I work in a safe environment".

Job and Career Satisfaction (JCS). This construct was measured with five items, with a sub-scale reliability of $\alpha=.84$ and includes questions relating to satisfaction with job and career aspects, such as "I am satisfied with the career opportunities available for me here". The Job and Career Satisfaction (JCS) factor seeks to measure the level to which a respondent feels their workplace provides sense of achievement, high self-esteem and fulfilment of potential.

Control at Work (CAW). This construct refers to the sense of control over decisionmaking at work, which can reflect the opportunities of voice and participation in decision making and has implications for health and well-being (Spector, 2002). This factor was measured using three items with a subscale reliability of $\alpha=0.86$, and an example item is: "I am involved in decisions that affect me in my own area of work".

Stress at Work (SAW). This factor assesses the extent to which an individual perceives they are subject to excessive pressure or experience of SAW. This construct was measured with four items, an example being "I often feel under pressure at work". The items were reversed, meaning that for this construct is presented in this paper as the Absence of SAW. Subscale reliability of this factor was $\alpha=.84$. 
Running Head: OVERTIME AND QUALITY OF WORKING LIFE IN ACADEMICS

General Well-Being (GWB). This factor assesses an individual's sense of psychological well-being and general physical health. This factor has a subscale reliability of .85 based on six items. An example of an item is: "I feel well at the moment".

Other variables. Our hypothesized research model also included the variables: role and additional working hours. Role was operationalized as a dichotomous variable where "1" represented academics and "0" represented non-academic staff working in HEI. Additional working hours per week were self-reported and measured with a categorical variable where $" 1 "=$ None, " $2 "=$ Five or less, " $3 "=$ Six to ten, " $4 "=$ Eleven to twenty, " $5 "=$ More than twenty. Age, gender, tenure (years at organization) and contract type ("1"=Permanent; "2"=Temporary) were added in our model as control variables.

\section{Data Analysis}

Data were analyzed via Structural Equation Modelling (SEM) with v22 of the IBM ${ }^{\circledR}$ SPSS $^{\circledR}$ Amos $^{\text {TM }}$ software (Arbuckle, 2012). We performed our analyses using a two-step approach as recommended by Anderson and Gerbing (1988). First, we tested five competitive measurement models in order to verify the most appropriate factorial structure for our variables with this data. Our hypothesized measurement model (HMM) contained the confirmatory factor analysis of the 7 factors previously studied for Quality of working life (HWI - work-life balance-, WCS, JCS, CAW, absence of SAW, ECO, and GWB), (Fontinha et al., 2016), role (academic vs non-academic), number of extra hours worked per week, as well as age, gender, contract type (permanent vs. temporary), and tenure as control variables.

The HMM was compared with four alternative models via chi-squared difference tests. The first alternative measurement model (AMM1) had a single factor where all items within the quality of working life scale loaded, as well as all remaining observable variables. The second alternative measurement model (AMM2) had two factors: all items within the WRQoL1 scale loaded on one and all remaining observable variables loaded on the other. 
Running Head: OVERTIME AND QUALITY OF WORKING LIFE IN ACADEMICS

The third alternative measurement model (AMM3) had all non-WRQoL1 observable variables set out to be independent (i.e., not loading in any factor) and all items within quality of working life loading on one factor. The fourth alternative measurement model (AMM4) had all observable variables set out to be independent and items from WRQoL1 loading on three factors: this three factor structure was inspired by previous research (Fontinha, Van Laar \& Easton, 2016), which probed a model where items form HWI, WCS, JCS and CAW were antecedents (first factor), items from ECO and absence of SAW can be mediators (second factor) and items from GWB can be outcomes within quality of working life.

Second, we tested our hypothesized structural model, depicted on figure 1 . This model contained two additional variables representing the interaction effects between role and additional working hours, and between role and work-life balance.

In order to assess the fit of the models we followed Bollen and Long's (1993) and Byrne's (2001) recommendations and used the following goodness-of-fit statistics: The comparative fit index (CFI), the goodness of fit index (GFI), the Tucker-Lewis index (TLI) also called the non-normed fit index, the root mean square error of approximation (RMSEA), and the standardized root mean square residual (SRMR). Values for CFI, GFI and TLI indicate an excellent fit when they equal to or exceed .95 . Values above .90 indicate a good fit. Values below .05 for RMSEA and values below .09 for SRMR indicate excellent fit, while values less than or equal to .08 and .10 , respectively, indicate a good fit. The $\chi^{2}$ difference test was used to compare the alternative measurement models.

\section{Results}

Means, standard deviations and correlations between our studied variables are presented on Table 2. On this table, we are able to observe that all outcome variables in our hypothesized model (WCS, JCS, CAW, absence of SAW, ECO, and GWB) are strongly correlated to each other. The means of WCS, JCS, CAW, absence of SAW, ECO, and GWB 
Running Head: OVERTIME AND QUALITY OF WORKING LIFE IN ACADEMICS

were then compared, and for academics and non-academics respectively were: WCS (3.48;

$3.70 ; \mathrm{t}=-9.59, \mathrm{p}<.001) ; \operatorname{JCS}(3.24 ; 3.41 ; \mathrm{t}=-5.90, \mathrm{p}<.001) ; \operatorname{CAW}(3.33 ; 3.53 ; \mathrm{t}=-6.13 ; \mathrm{p}<.001)$

$\operatorname{ECO}(3.27 ; 3.57 ; \mathrm{t}=-10.08, \mathrm{p}<.001) ;$ absence of SAW $(2.83 ; 3.32 ; \mathrm{t}=-16.09 ; \mathrm{p}<.001) ;$ and

GWB $(3.38 ; 3.49 ; \mathrm{t}=-3.98, \mathrm{p}<.001)$. The variables role (academic vs non-academic), worklife balance and number of extra hours worked were observed to correlate strongly with all remaining variables.

(Insert table 2 about here)

Table 3 presents the fit indices for our hypothesized measurement model (HMM), as well as the fit indices for other competing models (AMM1, AMM2, AMM3, AMM4). Alternative models were compared to HMM via chi-squared difference tests and results showed that HMM has a significantly better fit to our data. For this reason, HMM's factor structure was utilized for further structural analyses. Our hypothesized structural model (Figure 1) followed HMM's factorial pattern but two other variables were added: the variables testing the interactions between role and additional working hours, and between role and HWI. This model presented an adequate fit to our data: $\chi^{2}=4415.06 ; \mathrm{df}=430 \mathrm{p}<.001$; $\mathrm{GFI}=.92 ; \mathrm{TLI}=.91 ; \mathrm{CFI}=.94 ; \mathrm{RMSEA}=.05 ; \mathrm{SRMR}=.04$.

(insert Table 3 about here)

The regression weights for the different structural paths and their significance are presented on Table 4. Data partially supported our first hypothesis (H1) as being an academic (vs. a non-academic in higher education) was significantly related to a less favorable perception of working conditions $(\beta=-.04 ; \mathrm{p}<.05)$, lower perceived control at work $(\beta=-.07$; $p<.001)$, lower levels of commitment to the organization $(\beta=-.11 ; p<.001)$, and to lower rating in terms of absence of stress at work $(\beta=-.07 ; \mathrm{p}<.001)$. There were no significant differences between academics and non-academics regarding their job and career satisfaction 
and we found that academics tend to report higher levels of general well-being ( $\beta=.04$; $\mathrm{p}<.05)$.

Our second hypothesis anticipated that a higher number of working hours would exacerbate the negative relationship between role (academic vs. non-academic) and all elements of quality of working life. This hypothesis was partially supported by our data as we found that the interaction between role and additional working hours was significantly and negatively related to JCS $(\beta=-.04 ; \mathrm{p}<.05)$ and CAW $(\beta=-.08 ; \mathrm{p}<.001)$. However, contrary to what was expected this interaction was positively related to the absence of SAW $(\beta=.07$; $\mathrm{p}<.001)$

Our third hypothesis anticipated that the negative relationship between being an academic (vs. non-academic) and elements of quality of working life (WCS, JCS, CAW, SAW, ECO and GWB) is moderated by one's perception of work-life balance. We tested the effects of the interaction term between role (academic 1 vs. non-academic 0 ) and work-life balance and found that they were positively related to WCS $(\beta=.03 ; \mathrm{p}<.05)$ and $\operatorname{ECO}(\beta=.04$; $\mathrm{p}<.05)$. This indicates that academics who perceive they have a more balanced relationship between work and life will tend to report better WCS and be more committed to the HEI, partially supporting H3. The regression paths between the interaction term and JCS, CAW, SAW and GWB were not significant.

(insert Table 4 about here)

Regarding our control variables, it is relevant to mention that women reported significantly higher levels of stress at work $(\beta=-.03 ; p<.05)$ but higher levels of WCS $(\beta=.03$; $\mathrm{p}<.05)$, JCS $(\beta=.10 ; \mathrm{p}<.001), \operatorname{ECO}(\beta=.10 ; \mathrm{p}<.001)$ and GWB $(\beta=.05 ; \mathrm{p}<.001)$. Older workers reported lower levels of stress $(\beta=.05 ; \mathrm{p}<.01)$ and perceived their WCS as poorer $(\beta=-.06 ; p<.001)$. A longer tenure with the HEI is associated with higher levels of stress $(\beta=-$ $.12 ; \mathrm{p}<.001)$, with a poorer JCS $(\beta=-.06 ; \mathrm{p}<.01)$, a lower $\operatorname{ECO}(\beta=-.08 ; \mathrm{p}<.001)$ and a poorer 
Running Head: OVERTIME AND QUALITY OF WORKING LIFE IN ACADEMICS

GWB $(\beta=-.04 ; p<.05)$. Temporary workers reported higher levels of stress at work $(\beta=-.05$; $\mathrm{p}<.001)$, but a better GWB $(\beta=.05 ; \mathrm{p}<.01)$.

Furthermore, we were particularly surprised with the fact that the direct relationships between number of extra hours worked and JCS, WCS, CAW, ECO and GWB were positive. The only expected relationship was the negative relationship between number of extra hours worked and absence of stress at work. For these reasons, we decided to explore these results further and we tested our data for the existence of curvilinear relationships between the variables. Results suggest that there is a significant quadratic effect of the number of extra hours worked in the prediction of JCS $\left(\beta=-.15 \Delta R^{2}=.001 ; . \mathrm{p}<.05\right)$, CAW $\left(\beta=-.21 \Delta R^{2}=.002\right.$; $. \mathrm{p}<.01)$ and absence of SAW $\left(\beta=.23 \Delta R^{2}=.003 ; \mathrm{p}<.001\right)$. This means that there are two reversed U-curves describing the relationships between number of extra hours worked and both JCS and CAW, and a regular U-shaped curve describing the relationship between number of extra hours worked and absence of stress at work. These results are presented on Figure 2 and will be described in detail in the discussion section.

Figure 2. Additional hours worked in relation to job and career satisfaction, control at work and absence of stress at work

(insert Figure 2 about here)

\section{Discussion}

The main aim of this study was to compare academics and non-academics working in higher education regarding their quality of working lives, relying on the assumption that the first would have a more demanding role (Tytherleigh et al., 2005; Winefield et al., 2003), and thus a perceived poorer quality of working life. Furthermore, we investigated the role of the number of unpaid extra hours worked per week as a variable that would interact with role and exacerbate its negative relationship with absence of stress at work, job and career satisfaction, 
working conditions, control at work, commitment to the organization and general well-being. We additionally aimed to explore the role of perceived work-life balance as contextual variable. In particular, we explored the way in which the HEI allowed employees' the possibility to have a balanced work-life interface. This variable would interact with role and moderate the negative relationship between being an academic (vs. a non academic) and the different factors within quality of working life. Our results generally support our hypotheses, with the exception of specific nuances, a detailed account of which is described below.

Consistently with H1, academics are significantly more likely than non-academics in higher education to report higher levels of stress at work. This can be related to their large set of demands at work (Kinman, 2014) and possibly to the absence of sufficient resources (Demerouti et al., 2001), leading them to experience a negative form of stress (Le Fevre et al., 2003). Academics also report less favorable perception of working conditions, lower perceived control/participation on decision making at work, and lower levels of commitment to the organization. This set of findings is consistent with previous research where, compared to non-academics in the same organization, academics and researchers reported higher levels of stress related to work relationships, job security, resources and communication, pay and benefits (Tytherleigh et al., 2005), and psychological strain (Winefield et al., 2003).

However, while Winefield et al. (2003) found that non-academics were generally more satisfied with their jobs, our study did not identify significant differences between the two groups regarding the factor job and career satisfaction. We believe this may be due to the fact that our variable includes a career-focused element and it might be that although academics are more stressed, they are satisfied with their jobs and careers because they have much job autonomy, especially when it comes to research (Darabi, Macaskill \& Reidy, 2016). This may also be the reason to justify our unexpected finding that academics tend to report higher levels of general well-being than non-academics: their individual sense of achievement with 
research (Darabi et al., 2016) may potentially be an important factor for well-being, compared to that of non-academics, whose jobs are more oriented to the collective functioning of the HEI that they work for.

Our second hypothesis assumed that the number of extra hours worked per week exacerbated the differences between academics and non-academics postulated on H1. When testing $\mathrm{H} 2$, we found that it was partially supported by our data as the interaction between role and number of additional hours worked per week was significantly and negatively related to job and career satisfaction and to control over decision making at work. This means that academics who worked longer hours were less satisfied with their jobs and careers and experienced lower control over decision making at work, meaning that they perceived fewer opportunities to voice their opinions and participate in decision making. It could be argued that for academics, working longer hours is a necessary condition to cope with the demands of work (Kinman, 2014), especially when one has not yet achieved a desired job and a career stage that allows them more voice and participation. However, further research would be required to examine the impact of career stage and perceived achievement. More surprisingly and contrary to expected, the interaction between role and the number of additional hours worked per week was positively related to the absence of stress at work. One explanation may be that academics use extra hours to be able to actually comply with the multiple demands of their jobs. That is, if working overtime is needed to finish certain tasks, academics who cannot work for a sufficient number of extra-hours (for diverse reasons, such as family commitments), may find their work will end up 'piling up' and stress levels will increase.

Our third hypothesis was also partially verified. In particular, we found that if employees perceive to have the conditions for a balanced work-life interface, then the impact of having an academic (vs. a non-academic) role on working conditions and commitment to 
Running Head: OVERTIME AND QUALITY OF WORKING LIFE IN ACADEMICS

the organization is reduced. These results suggest that, as expected, if academics perceive that their HEI provides them the possibility of having a good work-life balance, then this will transform their often more negative perceptions of working conditions and commitment to the organization, into favorable perceptions. In other words, academics who perceive a balanced work-life interface will also have a more favorable opinion of the working conditions provided by the HEI and reciprocate with a higher level of commitment to the HEI (Fontinha et al., 2016). Job and career satisfaction, control at work, absence of stress at work and general well-being may be variables that are more associated to academic life itself and not as organization-specific as commitment and working conditions. This may have been the reason why the first set of factors were not affected by the interaction effect between conditions for work-life balance provided by the organization and role.

Although we did not explicitly establish a hypothesis regarding the relationships between the number of additional hours worked per week and the different elements within quality of working life, our structural model presented interesting results. Previous research has suggested a negative effect of hours of work on health (Sparks et al., 1997). Golden and Wiens-Tuers (2006) found that overtime work hours were generally associated with increased work stress, fatigue and work-family interference, which is also consistent with our results concerning stress at work. However, we also found significant and positive relationships between working additional hours and job and career satisfaction, working conditions, control at work, commitment to the organization and general well-being. Golden and WiensTuers's (2006) study sheds some light on the fact that if overtime is mandatory it may be more harmful compared to when it is non-mandatory. In our particular sample, overtime is not paid and not mandatory, although specific role demands may make it feel compulsory.

Given the unexpected nature of our findings, we decided to run further analyses and test for curvilinear relationships. We found that the relationships between number of extra 
hours worked and job and career satisfaction and control at work were inverted U-curves, meaning that employees who worked up to 10 extra hours were more satisfied with their job and career and felt they have more control over decision making at work, when compared to those who either worked a higher number of extra-hours or did not work overtime at all. This might be because workers who do not work overtime are in less challenging and powerful positions in the HEI, while those who work extremely long hours are struggling to achieve career success (e.g. early career academics and academics with specific high role demands including teaching and administrative loads), or it might be that the benefits of working up to 10 extra hours outweigh the costs of doing less or working inefficiently or too much. We additionally found a regular $\mathrm{U}$-shaped curve describing the relationship between number of extra hours worked and absence of stress at work. This helps explain the unexpected findings on H2. In particular, we may say that there is an optimal level of extra-hours that can be used to cope with stress and finish pending work, which is of about 5 hours or less. When employees work for 6 to 20 hours, there is a steep decrease in the reported absence of stress at work (thus they would feel significantly more stressed). This decrease becomes less accentuated when employees report to work more than 20 extra hours, which relates to the smaller difference between working from 10 to 20 hours and more than twenty hours: the absence of stress levels tend to stabilize at a very low point for these individuals.

\section{Limitations and Future Research Directions}

Despite its relevant contributions, this paper has limitations which are acknowledged. First, this study has a cross-sectional design, which makes it impossible to infer causal paths and clearly attest whether our antecedents 'cause' our outcomes. However, our hypotheses followed previous longitudinal empirical research (Frone, Russel \& Cooper, 1997) suggesting that our independent variables would indeed be likely to be antecedents of the different elements within quality of working life. We would recommend testing these results 
Running Head: OVERTIME AND QUALITY OF WORKING LIFE IN ACADEMICS

longitudinally and analyzing different cross-lagged paths in order to verify the directionality of our relationships.

A second limitation concerns the risk of common method variance due to using selfreported data. Questionnaires were the single source of data collection, and variables such as the number of extra-hours worked were self-reported. However, we used widely validated measures, which were built following Podsakoff et al.'s (2003) suggestions for questionnaire design to reduce the risk of common method variance (e.g., changes in the response format, anonymity, intermixing the items of different constructs on the questionnaire, instructing participants that there are no right or wrong answers). Furthermore, also following Podsakoff et al.'s (2003) suggestions, we used confirmatory factor analysis and compared several competing models via chi-squared difference tests, which reassures us that the factorial structure of the model is robust. Nevertheless, future research should account for the effect of more objective variables that could influence the number of working hours of academics, such as overall pay and the specific goals that need to be achieved (e.g. number of published papers needed to achieve a permanent position). One could anticipate that a higher overall pay could trigger the perceived need to work extra hours. The need to achieve publication goals, especially for academics on probation (tenure track) could additionally lead them to work overtime in order to achieve these goals and gain a permanent position.

The third limitation of our study refers to the fact that our data were only collected in HEIs in the United Kingdom. Although previous evidence suggests that academics work over time in different parts of the world (Coetzee \& Rothmann, 2005; Court, 1996; Kinman et al., 2006; Kinman \& Wray, 2013) it could be the case that contextual elements such as employment legislation could have influenced our results (the OECD, 2013, provided evidence that employment legislation tends to be more protective in Continental Europe, 
Running Head: OVERTIME AND QUALITY OF WORKING LIFE IN ACADEMICS

when compared to UK, but the latter tends to be more protective than in the USA or in Asian countries - OECD, 2013). Further research is needed to test our results in different contexts.

\section{Implications for Research and Practice}

The results of this study bring important contributions to both research on the quality of working life of academics and non-academics in HEI, and practice in terms of policymaking in the Higher Education context. First, this study extends existing research by comparing academics and non-academics in HEI, drawing upon an established set of factors from an overarching measure of quality of working life. Second, we highlight the importance of the role of overtime in exacerbating the relationship between being an academic (vs. a non-academic) and quality of working life, and the moderating role of a perceived organizational context that promotes work-life balance in this negative relationship. Third, we found curvilinear relationships between number of extra-hours worked and JCS, CAW and absence of SAW.

The relatively poor reported quality of working life of academics reinforces previous findings (Tytherleigh et al., 2005; Winefield et al., 2003) and is of relevance to HEI policy makers, given duty of care as regards the health and well-being of their staff. Furthermore, our results demonstrate that a favorable context that promotes work-life balance will tend to be associated with a higher commitment from an academic workforce, thereby potentially reducing expenses such as those due to staff turnover. These findings indicate that development of clear policies in relation to the promotion of maintaining work-life balance, and active monitoring and facilitation of such, should be a key focus for Higher Education Institutions. In particular, increasing control over working hours and helping academics achieve recovery from work demands could be used by Higher Education Institutions as interventions. 
Running Head: OVERTIME AND QUALITY OF WORKING LIFE IN ACADEMICS

\section{References}

Anderson, J. C., \& Gerbing, D. W. (1988). Structural equation modelling in practice: A review and recommended two-step approach. Psychological Bulletin, 103, 411423. http://dx.doi.org/10.1037/0033-2909.103.3.411

Araujo, E. R. (2008). Technology, gender and time: a contribution to the debate. Gender, Work and Organization, 15, 477-503. http://dx.doi.org/10.1111/j.14680432.2008.00414.x

Arbuckle, J. L. (2012). IMB ${ }^{\circledR} \operatorname{SPSS}^{\circledR}$ Amos $^{\mathrm{TM}} 21$ User's Guide. Amos Development Corporation.

Avanzi, L, van Dick, Fraccaroli, F., \& Sarchielli, G. (2012). The downside of organizational identification: Relations between identification, workaholism and wellbeing. Work \& Stress, 26, 289-307. http://doi:10.1080/02678373.2012.712291

Blanch, J. M., Sahagún, M., Cantera, L., \& Cervantes, G. (2010). Questionnaire of General Labour Well-being: Structure and Psychometric Properties. Revista de Psicología del Trabajo y de las Organisaciones, 26, 157-170.

http://dx.doi.org/10.5093/tr2010v26n3a2

Bollen, K. A., \& Long, J. S. (1993). Testing structural equation models. Newbury Park, CA: Sage.

Boswell, W. \& Olson-Buchanan, J. (2007). The use of communication technologies after hours: the role of attitudes and work-life conflict. Journal of Management, 33, 592-610. http://dx.doi.org/10.1177/0149206307302552

Byrne, B. M. (2001). Structural equation modeling with Amos. Basic concepts, application and programming. Mahwah, NJ: Erlbaum.

Catano, V. M., Francis, L., Haines, T., Kirpalani, H., Shannon, H., Stringer, B., \& Lozanski, L. (2010). Occupational stress in Canadian universities: A national 
Running Head: OVERTIME AND QUALITY OF WORKING LIFE IN ACADEMICS

survey. International Journal of Stress Management, 17, 232-258. http://dx.doi.org/10.1037/a0018582

Chiang, F. F. T., Birtch, T. A., \& Kwan, H. K. (2010). The moderating roles of job control and work-life balance practices on employee stress in the hotel and catering industry. International Journal of Hospitality Management, 29, 25-32. http://dx.doi.org/10.1016/j.ijhm.2009.04.005.

Coetzee, S. E., \& Rothmann, S. (2005). Occupational stress, organisational commitment and ill-health of employees at a higher education institution in South Africa. South African Journal of Industrial Psychology, 31, 47-54. http://dx.doi.org/10.4102/sajip.v31i1.179

Court, S. (1996). The use of time by academic and related staff. Higher Education Quarterly, 50, 237-260. http://dx.doi.org/10.1111/j.14682273.1996.tb01705.x

Currie, J., \& Eveline, J. (2011). E-technology and work/life balance for academics with young children. Higher Education, 62, 533-550.

http://dx.doi.org/10.1007/s10734-010-9404-9

Darabi, M., Macaskill, A., \& Reidy, L. (2016). A qualitative study of the UK academic role: positive features, negative aspects and associated stressors in a mainly teaching-focused university. Journal of Further and Higher Education, 1-15. http://dx.doi.org/10.1080/0309877X.2016.1159287

Demerouti, E., Bakker, A. B., Nachreiner, F., \& Schaufeli, W. B. (2001). The job demands-resources model of burnout. Journal of Applied Psychology, 86, 499-512. http://dx.doi.org/10.1037/0021-9010.86.3.499

Denvir, A., Hillage, J., Cox, A., Sinclair, A., \& Pearmain, D. (2008). Quality of working life in the $U K$ (research report 452). Sector Skills Development Agency. 
Running Head: OVERTIME AND QUALITY OF WORKING LIFE IN ACADEMICS

Dehghan, N., Tahmineh, S., \& Asadi, N. (2011). Quality of Work Life and Productivity among Iranian Nurses. Contemporary Nurse, 39, 106-118. http://dx.doi.org/10.5172/conu.2011.39.1.106

Doherty, L., \& Manfredi, S. (2006). Action research to develop work-life balance in a UK university. Women in Management Review, 21, 241-259. http://dx.doi.org/10.1108/09649420610657416

Dorsey, E. R., Jarjoura, D., \& Rutecki, G. W. (2003). Influence of controllable lifestyle on recent trends in specialty choice by US medical students. Journal of the American Medical Association, 290, 1173-1178.

http://dx.doi.org/10.1001/jama.290.9.1173

Doyle, C., \& Hind, P. (1998). Occupational stress, burnout and job status in female academics. Gender, Work and Organisation, 5, 67-82. http://dx.doi.org/10.1111/1468-0432.00047

Easton, S., \& Van Laar, D. L. (2012). User Manual of the WRQoL scale. Portsmouth: University of Portsmouth.

Easton, S., \& Van Laar, D. L. (2013). Evaluation of Outcomes and Quality of Working Life in the Coaching Setting. The Coaching Psychologist, 9, 71-77. ISSN 1748-1104

Edwards, J. A., Van Laar, D., Easton, S., \& Kinman, G. (2009). The work-related quality of life scale for higher education employees. Quality in Higher Education, 15, 207219. http://dx.doi.org/10.1080/13538320903343057

Elizur, D., \& Shye, S. (1990). Quality of work life and its relation to quality of life. Applied Psychology, 39, 275-291. http://dx.doi.org/10.1111/j.1464-0597.1990.tb01054.x

Fein, E. C., \& Skinner, N. (2015). Clarifying the effect of work hours on health through work-life conflict. Asia Pacific Journal of Human Resources, 53, 448-470. http://dx.doi.org/10.1111/1744-7941.12065 
Running Head: OVERTIME AND QUALITY OF WORKING LIFE IN ACADEMICS

Felce, D., \& Perry, J. (1995). Quality of life: Its definition and measurement. Research in developmental disabilities, 16, 51-74. http://dx.doi.org/10.1016/08914222(94)00028-8

Fontinha, R., Van Laar, D., \& Easton, S. (2016). Quality of working life of academics and researchers in the UK: the roles of contract type, tenure and university ranking. Studies in Higher Education, 1-18. http://dx.doi.org/10.1080/03075079.2016.1203890

Frone, M. R., Russel, M., \& Cooper, M. L. (1997). Relation of work-family conflict to health outcomes: A four-year longitudinal study of employed parents. Journal of Occupational and Organizational Psychology, 70, 325-335. http://dx.doi.org/10.1111/j.2044-8325.1997.tb00652.x

Gillespie, N. A., Walsh, M., Winefield, A. H., \& Stough, C. (2001). Occupational stress in universities: staff perceptions of the causes, consequences and moderators of stress. Work and Stress, 15, 3-72. http://dx.doi.org/10.1080/02678370117944

Golden, L., \& Wiens-Tuers, B. (2006). To your happiness? Extra hours of labor supply and worker well-being. The Journal of Socio-Economics, 35, 382-397. http://dx.doi.org/10.1016/j.socec.2005.11.039

Greenhaus, J., \& Beutell, N. (1985). Sources of Conflict between Work and Family Roles. The Academy of Management Review, 10, 76-88. Retrieved from http://www.jstor.org/stable/258214

HESA (2016). Staff 2011/2012. Retrieved from https://www.hesa.ac.uk/data-andanalysis/publications/staff-2011-12/introduction

Hobfoll, S. E. (1989). Conservation of Resources: A New Attempt at Conceptualizing Stress. American Psychologist, 44, 513-524. http://dx.doi.org/10.1037/0003066X.44.3.513 
Running Head: OVERTIME AND QUALITY OF WORKING LIFE IN ACADEMICS

Hogan, V., Hogan, M., Hodgins, M., Kinman, G., \& Bunting, B. (2014). An examination of gender differences in the impact of individual and organisational factors on work hours, work-life conflict and psychological strain in academics. The Irish Journal of Psychology, 35, 133-150. http://dx.doi.org/10.1080/03033910.2015.1011193

Johnsrud, L. K. (2002). Measuring the quality of faculty and administrative worklife: Implications for college and university campuses. Research in Higher Education, 43, 379-395. http://dx.doi.org/10.1023/A:1014845218989

Kalliath, T., \& Brough, P. (2008). Work-life balance: A review of the meaning of the balance construct. Journal of Management and Organization, 14, 323-327. doi:10.5172/jmo.837.14.3.323

Kelloway, E. K., Inness, M., Barling, J., Francis, L., \& Turner, N. (2010). Loving one's job: Construct development and implications for individual well-being. In P. L. Perrewé \& D. C. Ganster (Eds.), New Developments in Theoretical and Conceptual Approaches to Job Stress (pp.109 - 136). Emerald Group Publishing Limited. http://dx.doi.org/10.1108/S1479-3555(2010)0000008006

Kinman, G. (1998). Pressure points: A survey into the causes and consequences of occupational stress in UK academic and related staff. London: Association of University Teachers.

Kinman, G. (2014). Doing More with Less? Work and Wellbeing in Academics. Somatechnics, 4, 219-235. http://dx.doi.org/10.3366/soma.2014.0129

Kinman, G., \& Jones, F. (2004). Working to the Limit. London: AUT Publications. Kinman, G., \& Jones, F. (2008). Effort-reward imbalance, over-commitment and work-life conflict in UK academics. Journal of Managerial Psychology, 23, 236-251. http://dx.doi.org/10.1108/02683940810861365. 
Running Head: OVERTIME AND QUALITY OF WORKING LIFE IN ACADEMICS

Kinman, G., Jones, F., \& Kinman, R. (2006). The wellbeing of the UK academy, 19982004. Quality in Higher Education, 12, 15-27.

http://dx.doi.org/10.1080/13538320600685081

Kinman, G., \& Wray, S. (2013). Higher Stress: A Survey of Stress and Wellbeing among Staff in Higher Education. London: UCU Publications

Kinman, \& Wray, S. (2016). Work-related wellbeing in UK higher education. London: University and College Union.

Larkins, F. P. (2014). Trends in non-academic staff for Australian universities 2000-2010. Retrieved from http://www.lhmartininstitute.edu.au/userfiles/files/Blog/HE_PolicyAnalysis_FLar kins_June2012.pdf

Le Fevre, M., Matheny, J., \& Kolt, G. S. (2003). Eustress, distress, and interpretation in occupational stress. Journal of Managerial Psychology, 18, 726 - 744. http://dx.doi.org/10.1108/02683940310502412

Menzies, H. \& Newson, J. (2007). No time to think: Academics' life in the globally wired university. Time and Society, 16, 83-98. http://dx.doi.org/10.1177/0961463X07074103

Metcalf, H., Rolfe, H., Stevens, P. \& Weale, M. (2005). Recruitment and retention of academic staff in higher education National Institute of Economic and Social Research (Research Report RR658). London: DFES.

Netemeyer, R. G., Boles, J. \& McMurrian, R. (1996). Development and validation of workfamily conflict and family-work conflict scales. Journal of Applied Psychology, 81, 400-410. http://dx.doi.org/10.1037/0021-9010.81.4.400

Noor, K. M. (2011). Work-life balance and intention to leave among academics in Malaysian public higher education institutions. International Journal of Business and Social 
Running Head: OVERTIME AND QUALITY OF WORKING LIFE IN ACADEMICS

Science, 11, 240-248. Retrieved from http://ijbssnet.com/journals/Vol._2_No._11_[Special_Issue-June_2011]/34.pdf

OECD (2013). Detailed description of employment protection legislation - 2012-2013 OECD Countries. Retrieved from http://www.oecd.org/els/emp/All.pdf

Pillay, S., \& Abhayawansa, S. (2014). Work-family balance: perspectives from higher education. Higher Education, 68, 669-690. http://dx.doi.org/10.1007/s10734-0149738-9

Pillay, S., Kluvers, R., Abhayawansa, S., \& Vranic, V. (2013). An exploratory study into work/family balance within the Australian higher education sector. Higher Education Research \& Development, 32, 228-243.

http://dx.doi.org/10.1080/07294360.2012.679645

Podsakoff, P. M., Mackenzie, S. B., Lee, J. Y., \& Podsakoff, N. P. (2003). Common method bias in behavioral research: A critical review of the literature and recommended remedies. Journal of Applied Psychology, 88, 879-903. http://dx.doi.org/10.1037/0021-9010.88.5.879

Schaufeli, W. B., \& Taris, T. W. (2014). A critical review of the job demands-resources model: implications for improving work and health. In G. F. Bauer \& O. Hämmig (Eds.), Bridging Occupational, Organizational and Public Health: A Transdisciplinary Approach, (pp.43-68). Dordrecht: Springer Science.

Siegrist, J. (1996). Adverse health effects of high effort - low reward conditions at work. Journal of Occupational Health Psychology, 1, 27-43. http://dx.doi.org/10.1037/1076-8998.1.1.27

Siegrist, J. (2001). A theory of occupational stress. In J. Dunham (Ed.), Stress in the workplace: Past, present and future. London: Whurr Publishers. 
Running Head: OVERTIME AND QUALITY OF WORKING LIFE IN ACADEMICS

Sparks, K., Cooper, C., Fried, Y., \& Shirom, A. (1997). The effects of hours of work on health: A meta-analytic review. Journal of Occupational and Organisational Psychology, 70, 391-408. http://dx.doi.org/10.1111/j.2044-8325.1997.tb00656.x

Spector, P. E. (2002). Employee control and occupational stress. Current Directions in Psychological Science, 11, 133-136. http://dx.doi.org/10.1111/1467-8721.00185

Statistical Bulletin (2013). Annual Survey of Hours and Earnings, 2013 Provisional Results.

Office for National Statistics: UK. Retrieved from

http://webarchive.nationalarchives.gov.uk/20160105160709/http://www.ons.gov. uk/ons/dcp171778_335027.pdf

Taylor, J. C., Cooper, C. L., \& Mumford, E. (1979). The quality of working life in Western and Eastern Europe. ABP.

The Complete University Guide (2017). University League Tables. Retrieved from http://www.thecompleteuniversityguide.co.uk/league-tables/rankings

The Guardian (2017). University League Tables. Retrieved from https://www.theguardian.com/news/datablog/2009/jun/02/universityguide$\underline{\text { choosingadegree }}$

Tytherleigh, M., Webb, C., Cooper, C., \& Ricketts, C. (2005). Occupational stress in UK higher education institutions: A comparative study of all staff categories. Higher Education Research \& Development, 24, 41-61.

http://dx.doi.org/10.1080/0729436052000318569

Vagharseyyedin, S. A., Vanaki, Z., \& Mohammadi, E. (2011). Quality of Work Life: Experiences of Iranian Nurses. Nursing and Health Sciences, 13, 65-75. http://dx.doi.org/10.1111/j.1442-2018.2011.00581.x 
Running Head: OVERTIME AND QUALITY OF WORKING LIFE IN ACADEMICS

Van Laar, D. L., Edwards, J., \& Easton, S. (2007). The Work-Related Quality of Life (WRQoL) Scale for Healthcare Workers. Journal of Advanced Nursing, 60, 325333. http://dx.doi.org/10.1111/j.1365-2648.2007.04409.x

Whitley, R., \& Gläser, J. (2014). The impact of institutional reforms on the nature of universities as organisations. Research in the Sociology of Organizations, 42, 1949. http://dx.doi.org/10.1108/S0733-558X20140000042000

Winefield, A. H., Gillespie, N., Stough, C., Dua, J., Hapuarachchi, J. R., and Boyd, C. M. (2003). Occupational stress in Australian university staff: results from a national survey. International Journal of Stress Management, 10, 51-63. http://dx.doi.org/10.1037/1072-5245.10.1.51

Winefield, H. R., Boyd, C., \& Winefield, A. H. (2014). Work-family conflict and well-being in university employees. The Journal of Psychology, 148, 683-697. http://dx.doi.org/10.1080/00223980.2013.822343

Winefield, A., Boyd, C., Saebel, J., \& Pignata, S. (2008). Job stress in university staff: An Australian research study. Bowen Hills, Queensland: Australian Academic Press. 
Running Head: OVERTIME AND QUALITY OF WORKING LIFE IN ACADEMICS

Table 1. Sample characteristics

\begin{tabular}{|c|c|c|}
\hline & Non-academics & Academics \\
\hline \multicolumn{3}{|l|}{ Gender: } \\
\hline Male & 606 & 710 \\
\hline Female & 1347 & 764 \\
\hline \multicolumn{3}{|l|}{ Age (Years): } \\
\hline Under 25 & 107 & 20 \\
\hline $25-44$ & 1016 & 741 \\
\hline $45-59$ & 731 & 614 \\
\hline 60 or over & 99 & 99 \\
\hline \multicolumn{3}{|l|}{ Tenure (Years): } \\
\hline Less than 1 & 252 & 141 \\
\hline 1 to 2 & 735 & 536 \\
\hline 3 to 5 & 392 & 295 \\
\hline 6 to 10 & 391 & 342 \\
\hline 11 to 20 & 178 & 149 \\
\hline more than 20 & 5 & 11 \\
\hline \multicolumn{3}{|l|}{ Number of extra-hours: } \\
\hline None & 536 & 114 \\
\hline 5 or less & 794 & 365 \\
\hline 6 to 10 & 431 & 509 \\
\hline 11 to 20 & 161 & 349 \\
\hline More than 20 & 31 & 137 \\
\hline \multicolumn{3}{|l|}{ Time: } \\
\hline Full time & 331 & 182 \\
\hline Part time & 1540 & 1254 \\
\hline Part time hourly paid & 80 & 34 \\
\hline No fixed hours & 2 & 4 \\
\hline \multicolumn{3}{|l|}{ Contract type: } \\
\hline Temporary & 266 & 470 \\
\hline Permanent & 1687 & 1004 \\
\hline
\end{tabular}




\section{Running Head: OVERTIME AND QUALITY OF WORKING LIFE IN ACADEMICS}

Table 2. Means, Standard Deviations and Correlation Matrix

\begin{tabular}{|c|c|c|c|c|c|c|c|c|c|c|c|c|c|c|}
\hline & Mean & SD & 1 & 2 & 3 & 4 & 5 & 6 & 7 & 8 & 9 & 10 & 11 & 12 \\
\hline $\begin{array}{l}\text { 1. Gender }(1= \\
\text { Male; } 2=\text { Female })\end{array}$ & 1.62 & .49 & 1 & & & & & & & & & & & \\
\hline 2. Age & 2.47 & .66 & $-.14 * * *$ & 1 & & & & & & & & & & \\
\hline 3. Tenure & 2.82 & 1.20 & $-.14 * * *$ & $.48 * * *$ & 1 & & & & & & & & & \\
\hline $\begin{array}{l}\text { 4. Role } \\
\text { (Academic }=1 ; \\
\text { Non-Academic }= \\
\text { 0) }\end{array}$ & .43 & .50 & $-.17 * * *$ & $.09 * * *$ & $.06 * * *$ & 1 & & & & & & & & \\
\hline $\begin{array}{l}\text { 5. Additional } \\
\text { working hours } \\
\text { (per week) }\end{array}$ & 2.53 & 1.11 & $-.19 * * *$ & $.15^{* * *}$ & $.17 * * *$ & $.39 * * *$ & 1 & & & & & & & \\
\hline $\begin{array}{l}\text { 6. Contract type } \\
(\text { Permanent }=1 \text {; } \\
\text { Temporary }=0)\end{array}$ & .79 & .41 & $-.08 * * *$ & $.20 * * *$ & $.30 * * *$ & $-.22 * * *$ & $.04 *$ & 1 & & & & & & \\
\hline $\begin{array}{l}\text { 7. Work-Life } \\
\text { Balance }\end{array}$ & 3.55 & .92 & $.07 * * *$ & -.02 & $-.10 * * *$ & $-.16^{* * *}$ & $-.37 * * *$ & $-.06 * * *$ & 1 & & & & & \\
\hline 8. WCS & 3.61 & .82 & $.07 * * *$ & $-.07 * * *$ & $-.10 * * *$ & $-.14 * * *$ & $-.21 * * *$ & -.03 & $.59 * * *$ & 1 & & & & \\
\hline 9. JCS & 3.34 & .85 & $.12 * * *$ & $-.05 * *$ & $-.11 * * *$ & $-.10 * * *$ & $-.14 * * *$ & -.03 & $.54 * * *$ & $.69 * * *$ & 1 & & & \\
\hline 10. CAW & 3.45 & .96 & $.04 *$ & -.01 & $-.04 *$ & $-.10^{* * *}$ & $-.07 * * *$ & -.02 & $.47 * * *$ & $.61 * * *$ & $.75^{* * * *}$ & 1 & & \\
\hline 11. ECO & 3.44 & .88 & $.15^{* * *}$ & $-.06 * *$ & $-.15 * * *$ & $-.17 * * *$ & $-.19 * * *$ & $-.05 * *$ & $.52 * * *$ & $.71 * * *$ & $.69 * * *$ & $.60 * * *$ & 1 & \\
\hline $\begin{array}{l}\text { 12. (Absence of) } \\
\text { SAW }\end{array}$ & 3.11 & .93 & $.10 * * *$ & $-.08 * *$ & $-.21 * * *$ & $-.27 * * *$ & $-.56 * * *$ & $-.10^{* * *}$ & $.605 * * *$ & $.48^{* * *}$ & $.42 * * *$ & $.34 * * *$ & $.44 * * *$ & 1 \\
\hline 13. GWB & 3.44 & .83 & $.07 * * *$ & .01 & $-.08 * * *$ & $-.07 * * *$ & $-.17 * * *$ & -.02 & $.65 * * *$ & $.64 * * *$ & $.65 * * *$ & $.56 * * *$ & $.56^{* * * *}$ & $.49 * * *$ \\
\hline
\end{tabular}


Running Head: OVERTIME AND QUALITY OF WORKING LIFE IN ACADEMICS

Table 3. Hypothesized measurement model (HMM) fit, alternative measurement models' fit and comparisons between models

\begin{tabular}{lccccccccc}
\hline & $\chi^{2}$ & $\mathrm{df}$ & Sig. & GFI & TLI & CFI & RMSEA & SRMR & $\Delta \chi^{2} ; \Delta$ df; Sig. \\
\hline HMM & 4319.35 & 392 & $\mathrm{p}<.001$ & .93 & .92 & .94 & .05 & .04 & \\
AMM1 & 19912.06 & 464 & $\mathrm{p}<.001$ & .64 & .66 & .68 & .11 & .12 & $\begin{array}{c}\text { AMM1 }-\mathrm{HMM} \\
15592.71 ; 72 ; \mathrm{p}<.001\end{array}$ \\
AMM2 & 18764.69 & 463 & $\mathrm{p}<.001$ & .66 & .68 & .70 & .11 & .09 & $\begin{array}{c}\text { AMM2 - HMM } \\
14445.34 ; 71 ; \mathrm{p}<.001\end{array}$ \\
AMM3 & 17587.20 & 449 & $\mathrm{p}<.001$ & .67 & .67 & .72 & .11 & .08 & $\begin{array}{c}\text { AMM3 }-\mathrm{HMM} \\
13267.85 ; 57 ; \mathrm{p}<.001 \\
\text { AMM4 }\end{array}$ \\
AMM4 & 13527.11 & 434 & $\mathrm{p}<.001$ & .73 & .75 & .78 & .09 & .07 & $\begin{array}{c}\text { AMM } \\
9207.76 ; 42 ; \mathrm{p}<.001\end{array}$ \\
\hline
\end{tabular}


Running Head: OVERTIME AND QUALITY OF WORKING LIFE IN ACADEMICS

Table 4. Detailed description of the regression paths in the final hypothesized structural equation model

\begin{tabular}{|c|c|c|c|c|c|c|}
\hline & \multicolumn{6}{|c|}{ Outcome Latent Variables } \\
\hline & WCS & JCS & CAW & $\mathrm{ECO}$ & $\begin{array}{l}\text { (Absence } \\
\text { of) SAW }\end{array}$ & GWB \\
\hline \multicolumn{7}{|l|}{ Main Variables: } \\
\hline Role $($ Academic $=1 ;$ Non-Academic $=0)$ & $-.04 *$ & -.02 & $-.07 * * *$ & $-.11 * * *$ & $-.07 * * *$ & $.04 *$ \\
\hline Additional working hours (per week) & $.10 * * *$ & $.17 * * *$ & $.23 * * *$ & $.13 * * *$ & $-.05 * * *$ & $.05 * * *$ \\
\hline Work-Life Balance & $.74 * * *$ & $.67 * * *$ & $.61 * * *$ & $.62 * * *$ & $.55 * * *$ & $.79 * * *$ \\
\hline Role*Additional working hours & -.01 & $-.04 *$ & $-.08 * * *$ & -.01 & $.07 * * *$ & .02 \\
\hline Role*Work-Life Balance & $.03 *$ & -.00 & .02 & $.04 *$ & .01 & .03 \\
\hline \multicolumn{7}{|l|}{ Control Variables: } \\
\hline Gender $(1=$ Male; $2=$ Female $)$ & $.03 *$ & $.10 * * *$ & .02 & $.10^{* * *}$ & $-.03^{*}$ & $.05 * * *$ \\
\hline Age & $-.06 * * *$ & -.03 & -.02 & -.00 & $.05 * *$ & .01 \\
\hline Tenure & -.02 & $-.06 * *$ & -.00 & $-.08 * * *$ & $-.12 * * *$ & $-.04 *$ \\
\hline $\begin{array}{l}\text { Contract type (Permanent }=1 \text {; Temporary } \\
=0)\end{array}$ & .02 & .03 & .01 & .01 & $-.05 * * *$ & $.05 * *$ \\
\hline
\end{tabular}

Note: ${ }^{*}=\mathrm{p}<.05 ; * *=\mathrm{p}<.01 ; * * *=\mathrm{p}<.001 ; \mathrm{WCS}=$ Working Conditions; JCS = Job and Career Satisfaction; CAW = Control at Work; ECO = Employee Commitment to the Organization; (Absence of) SAW = Absence of Stress at Work; GWB = General Well-Being 